\title{
British Journal of Pharmaceutical Research
}

16(4): 1-10, 2017; Article no.BJPR.33403

ISSN: 2231-2919, NLM ID: 101631759

\section{Antiangiogenic and Apoptotic Effects of Oleuropein on Breast Cancer Cells}

\author{
Recep Liman ${ }^{1 *}$, Funda Karabağ Çoban ${ }^{1}$, Ibrahim Hakkı Ciğerci ${ }^{2}$, \\ Ibrahim Bulduk ${ }^{3}$ and Selahattin Bozkurt ${ }^{4}$ \\ ${ }^{1}$ Department of Molecular Biology and Genetics, Faculty of Arts and Sciences, Usak University, \\ Usak 64200, Turkey. \\ ${ }^{2}$ Department of Molecular Biology and Genetics, Faculty of Arts and Sciences, Afyon Kocatepe \\ University, Afyon 03200, Turkey. \\ ${ }^{3}$ School of Health Sciences, Usak University, Uşak 64200, Turkey. \\ ${ }^{4}$ Vocational School of Health Science, Usak University, Uşak 64200, Turkey.
}

\section{Authors' contributions}

This work was carried out in collaboration between all authors. Authors RL, FKC and IHC designed the study and prepared the manuscript. Authors RL and FKC managed the literature searches. Authors IB and SB prepared oleuropein. All authors read and approved the final manuscript.

Article Information

DOI: $10.9734 / B J P R / 2017 / 33403$

Editor(s):

(1) Wenbin Zeng, School of Pharmaceutical Sciences, Central South University, Hunan, China.

Reviewers:

(1) Alicia García Falgueras, The Official College of Psychologists, Madrid, Spain.

(2) Michel Mansur Machado, Federal University of Pampa, Campus Uruguaiana, Brazil. Complete Peer review History: http://www.sciencedomain.org/review-history/18984

Original Research Article

Received $13^{\text {th }}$ April 2017

Accepted $4^{\text {th }}$ May 2017

Published $9^{\text {th }}$ May 2017

\section{ABSTRACT}

Oleuropein is a fundamental polyphenol contained in olive fruit, oil, and leaf, with a bitter taste. A decrease in its level is observed as the fruit ripens. Leaves of oil tree were used in this study as a possible origin of oleuropein. In this study, cytotoxic, genotoxic, apoptotic and antiangiogenic impacts of isolated oleuropein $\left(0.5 \times I_{50}, \quad I_{50}\right.$ and $\left.2 x I_{50}\right)$ on MCF-7 human breast adenocarcinoma cells were examined by means of 3-[4,5- Dimethylthiazol-2-yl] 1-2,5diphenyltetrazolium bromide (XTT) kit, Comet assay, Poly (ADP-Ribose) Polymerase (PARP) cleavage ELISA Kit and Vascular Endothelial Growth Factor (VEGF) Human ELISA Kit for 24, 48 and $72 \mathrm{~h}$, respectively. The $\mathrm{IC}_{50}$ value of oleuropein on MCF-7 cells was found to be $11.02 \pm 0.52$, $9.43 \pm 0.41$ and $6.81 \pm 0.18 \mu \mathrm{g} / \mathrm{mL}$ for 24,48 and $72 \mathrm{~h}$, respectively. The time and concentrationrelated cytotoxic impacts of oleuropein were determined to be significant. Cleaved PARP level was 
significantly increased especially with an increase in the concentration of oleuropein. However, a significant decrease in VEGF level was observed $(p<0.05)$. Furthermore, oleuropein increased damage on DNA for 48 and $72 \mathrm{~h}$. Findings showed oleuropein as a potential antiangiogenic, apoptotic and genotoxic agent for the breast cancer cells.

Keywords: Oleuropein; VEGF; PARP; MCF-7; comet.

\section{INTRODUCTION}

The most common type of cancer is breast cancer. At the same time, it represents the main reason for cancer-related deaths in women around the world [1]. An increase in the burden of breast cancer is observed in developing countries, and its mortality is excessively high [2]. Moreover, changes in the nutritional habits lead to an increase in the occurrence of breast cancer everywhere throughout the world. Much of this international variation is due to differences in established reproductive risk factors such as age at menarche, parityandage at births, and breast feeding but differences in dietary habits and physical activity may also contribute [3]. However, the occurrence of cancer in the countries situated in the Mediterranean region is relatively lower when compared to other European countries and the United States [4]. The nutritional practices are among the main causes of this, along with potential genetic factors. Products of plant origin at a high rate, red meat at a relatively low rate, and olive oil and its products at a high rate are included in the conventional Mediterranean diet.

Various studies on positive health impacts of olive oil are encountered in the literature. In some studies it was stated that olive oil is more advantageous against cancer when compared to other forms of added lipids since a large number of monounsaturated fatty acids are contained in it [5-10].

Three classes of polyphenols, hydroxytyrosol, secoiridoid such as oleuropein and lignans that demonstrate exceptional antioxidant activities present in olive oil in a large amount [6]. Phenolic compound that presents in olives at the highest rate is oleuropein [11]. As a result of the studies conducted, various pharmacologic and health promoting characteristics of oleuropein, such as antiatherogenic [12], antiviral [13], antimicrobial [14], hypotensive [15], and antidiabetic impacts [16], were determined. A great number of the aforementioned characteristics have been described because of the antioxidant nature of oleuropein [17-19]. Accordingly, oleuropein and hydroxytyrosol, being the metabolite of oleuropein, have anti-cancer features. Actually, high doses of oleuropein led to a decrease in cell viability and inhibition of cell growth in MCF-7 breast cancer cells [11].

Poly (ADP-ribose) polymerases (PARPs) are characterized as cell signaling enzymes which are responsible for catalyzing the transfer of ADP-ribose units from $\mathrm{NAD}^{+}$to some acceptor proteins. PARP-1 is a member of the PARP family defined in the best way and at the moment it contains 18 members. PARP-1 represents an abundant nuclear enzyme causing cellular reactions to DNA damage induced by genotoxic stress. PARP plays a role in DNA repair and transcriptional regulation and is currently considered to play a key role in cell survival and cell death. Furthermore, it is accepted as a master component of many transcription factors which are involved in tumor development [20].

Angiogenesis is a typical phenomenon in breast cancer and it has a key part in tumor advancement and breast cancer metastasis $[21,22]$. Tumor angiogenesis is defined as a process of creation of new blood vessels from prior ones. Three different modified cell functions of endothelial cells describe it enabling new possibilities for antiangiogenic therapy, such as crosstalk with the extracellular matrix, slow migration and rapid increase in cell growth, therefore ensuring new cells for vessel elongation [23]. There is often a correlation between the development of breast tumor and excessive angiogenesis. Accordingly, it causes us to determine and generate new therapeutic strategies for the prevention of angiogenic process [24]. The overexpression of VEGF is observed in different solid tumors, and it induces the generation of new blood vessels [25-27]. Besides, the molecular mechanisms that determine the impacts of PARP on angiogenesis are not fully investigated yet. However, in order to prevent VEGF-induced proliferation, migration, and tube formation in tumor models, minimum five PARP inhibitors have been employed in vitro in an efficient way [28-30].

In accordance with these data, dose dependent cytotoxic, genotoxic, apoptotic and antiangiogenic impacts of oleuropein on MCF-7 
human breast adenocarcinoma cells were examined in this study.

\section{MATERIALS AND METHODS}

\subsection{Extraction Procedure}

The isolation of oleuropein was performed from Olea europaea leaves described previously [31]. Olive tree leaves gathered in Uşak Province in June 2014 were used for the extraction of oleuropein. The procedure of drying the leaves was performed at room temperature for a period of 15 days. Afterwards, they were crushed by means of the mill (Retsch ZM 200, Haan, Germany) and sieved to a size of $80-100 \mu \mathrm{m}$ mesh. The extraction of the leaves in the form of powder $(100 \mathrm{~g})$ was performed with $600 \mathrm{~mL}$ ethanol $(\mathrm{EtOH})$ by applying intermittent stirring at $30^{\circ} \mathrm{C}$ for $1 \mathrm{~h}$. Whatman filter paper was used for the filtering of the EtOH extract, and the evaporation of the solvent was performed under decreased pressure below $40^{\circ} \mathrm{C}$. The residue of green color was again dried in a vacuum oven at $30-35^{\circ} \mathrm{C}$, producing $7 \mathrm{~g}$ oleuropein.

\subsection{Determination of the Antiproliferative Impact of Oleuropein on MCF-7 Cells}

In this study, the MCF-7 cell line, being a model cell line for human mammary carcinoma, was employed. A number of properties of differentiated mammary epithelium present in this cell line and it was preserved as an attached type monolayer culture in RPMI 1640 medium to which $10 \%$ heat-inactivated fetal bovine serum, L-glutamine, and antibiotics were added. It was kept under the conditions of incubation at $37^{\circ} \mathrm{C}$ in a humidified atmosphere of $5 \% \mathrm{CO}_{2}$. The effect of the oleuropein on the growth of MCF-7 cell line was examined using 96-well microtiter plates. The XTT cell proliferation kit was used for the assessment of the antiproliferative impact of oleuropein on MCF-7 cells. Briefly, cells were seeded into 96-well microtiter plates $\left(5 \times 10^{3}\right.$ cells/well) and their incubation was performed for $24 \mathrm{~h}, 48 \mathrm{~h}$, and $72 \mathrm{~h}$ in a medium containing horizontal dilutions of the compound. Then, XTT reagent was implemented in order to produce a soluble dye measured at $490 \mathrm{~nm}$ with an ELISA reader (Biotek). Cell viability on control wells was set to $100 \%$. Means of viable cell numbers at various oleuropein concentrations were given in the form of a percentage of the control. The curve of percent cell growth versus log (oleuropein concentration) shows the antiproliferative impact of the drug on cells. The prevention of cell growth and $\mathrm{IC}_{50}$ values were evaluated. The results were derived from the data of at least three assays.

\subsection{Determination of DNA Damage}

The analysis of DNA injury was performed with the COMET assay as mentioned earlier with small modifications [31]. MCF-7 cells were subjected to oleuropein $\left(0.5 \times \mathrm{IC}_{50}, \quad \mathrm{IC}_{50}\right.$ and $2 \times \mid C_{50}$ ), negative and positive control (Paclitaxel, $10 \mu \mathrm{M}$ ) for 24,48 and $72 \mathrm{~h}$. Afterwards, the cells were scraped, washed two times $(300 \mathrm{~g}, 10 \mathrm{~min}$, $\left.4^{\circ} \mathrm{C}\right)$ with cold $1 \times$ PBS $\left(\mathrm{Ca}^{2+} / \mathrm{Mg}^{2+}\right.$ free $)$, and suspended again in $1 \mathrm{~mL}$ of cold $1 \times$ PBS. $30 \mu \mathrm{l}$ of the cell suspension and $120 \mu \mathrm{l}$ of $0.8 \%$ agarose with a low melting point were mixed. Then, the mixture was spread on a cold slide, the pre-coating of which was performed with a layer of $1.0 \%$ agarose with a normal melting point which was covered by cover slips and kept at cold slabs for $5 \mathrm{~min}$. The slides were then immersed in a newly prepared cold $\left(4^{\circ} \mathrm{C}\right)$ lysis solution $(2.5 \mathrm{M} \mathrm{NaCl}, 1 \%$ Nasarcosine, $100 \mathrm{mM}$ EDTA-Na2, $10 \mathrm{mM}$ Tris- $\mathrm{HCl}$, pH 10-10.5; $1 \%$ Triton X-100 with $10 \%$ DMSO that was added just before application) for minimum $1 \mathrm{~h}$. Electrophoresis (25 V/300 mA, $25 \mathrm{~min})$ was carried out in a newly prepared alkaline electrophoresis buffer $(0.3 \mathrm{M} \mathrm{NaOH}$ and $1 \mathrm{mM}$ EDTA-Na2, $\mathrm{pH}>13$ ) at $4^{\circ} \mathrm{C}$ for the purpose of unwinding (40 $\mathrm{min})$. All stages were performed under the least illumination possible. Following the electrophoresis, the slides were washed $(0.4$ $\mathrm{M}$ Tris- $\mathrm{HCl}, \mathrm{pH} 7.5$ ) for the period of $5 \mathrm{~min}$ and their staining with $2 \mu \mathrm{g} / \mathrm{mL}$ ethidium bromide (70 $\mu \mathrm{L} /$ slide) was performed. Afterwards, the slides were covered with a coverslip, and a fluorescence microscope was used for the analysis. The analysis of 100 comets on 3 slides was performed visually by means of a fluorescent microscope (Olympus BX50, Japan) in the comet tail was assigned values such as 0 , $1,2,3$ or 4 (depending upon the degree of damage).

\subsection{Measurement of Cleaved PARP Levels}

Cleaved PARP levels were determined by using PARP ELISA kit (Elisa Cleaved PARP Kit).Cleaved PARP Human ELISA (EnzymeLinked Immunosorbent Assay) kit is an in vitro enzyme-linked immunosorbent assay for the quantitative measurement of $89 \mathrm{kDa}$ fragment of Human PARP-1 in cell and tissue lysates, including lysates of adherent and suspension 
cells grown in 96-well microplate format and lysed directly in culture media. The assay employs an antibody specific for the $89 \mathrm{kDa}$ fragment of Human PARP-1 coated onto well plate strips. This antibody reacts with the $\mathrm{N}$ terminal end formed by the cleavage adjacent to Asp214; It thus recognizes the apoptosis-specific $89 \mathrm{kDa}$ catalytic domain fragment, but it does not recognize the full-length PARP-1 or the $24 \mathrm{kDa}$ DNA binding domain fragment. Standards and samples was pipetted into the wells and analyzed present in the sample that bound to the wells by the immobilized antibody. The wells were washed and an anti-PARP-1 primary detector antibody was added. After washing away unbound primary detector antibody, HRPlabel specific for the primary detector antibody was pipetted to the wells. The wells were again washed, a TMB substrate solution was added to the wells and color develops in proportion to the amount of analyte bound. The developing blue color was measured at $600 \mathrm{~nm}$.

\subsection{Measurement of VEGF Levels}

MCF-7 cells were treated like Comet assay. VEGF levels were determined by using ELISA kit (USA \& Canada/R\&D Systems, Inc.).

The pre-coating of a monoclonal antibody which is particular for VEGF had been performed onto a microplate. Standards and samples were pipetted into the wells. At the same time, any VEGF found was bounded by the antibody which was immobilized. Following washing away all substances that were unbound, the supplementing of an enzyme-linked polyclonal antibody particular for VEGF was done to the wells. Subsequent to washing, a substrate solution was supplemented to the wells and color developed proportionately to the amount of VEGF that was bound at the initial stage. The development of the color was ended and the measurement of the color intensity was performed. Briefly; assay employs a specific capture antibody coated on a 96 wellplate. Standards and samples are pipetted into the wells and the target protein present in a sample is bound to the wells by the immobilized antibody. The wells are washed and a biotinylated detection antibody specific forthe target protein is added. After washing away unbound biotinylated antibody, HRP-conjugated streptavidin is pipetted tothewells. The wells areagain washed, a TMB substrate solution is added to the wells and color develops in proportion to the amount of target protein bound.
The Stop Solution changes the color from blue to yellow, and the intensity of the color is measured at $450 \mathrm{~nm}$.

\subsection{Statistical Analyses}

Experimental results were presented in the form of means and standard deviation of means $( \pm$ $\mathrm{SD}$ ), two-tailed t test and one-way analysis of variance (ANOVA) was employed for their analysis, after which Duncan post-hoc tests were performed on SPSS (18.0) software computer program. A difference between mean values of $p$ $<0.05$ was regarded as significant. The correlation analysis was used for the determination of dose response relationships.

\section{RESULTS}

\subsection{Impact of Oleuropein on the Inhibition of Cell Proliferation in MCF-7 Cells}

Treatment of MCF-7 cells was performed with various doses of oleuropein for 24,48 and $72 \mathrm{~h}$ (Fig. 1). A decrease in the cell viability of MCF-7 cells was observed as a result of the dosedependent incubation of cells with oleuropein for 24, 48 and $72 \mathrm{~h}$. The antiproliferative activity of oleuropein after 48 and $72 \mathrm{~h}$ was found stronger than that after $24 \mathrm{~h}$. The $\mathrm{IC}_{50}$ value of oleuropein on MCF-7 cells was found to be $11.02 \pm 0.52$, $9.43 \pm 0.41$ and $6.81 \pm 0.18 \mu \mathrm{g} / \mathrm{mL}$ for 24,48 and $72 \mathrm{~h}$, respectively (Table 1 ). As the incubation period increased the $\mathrm{IC}_{50}$ values decreased which means that the oleuropein exhibited a more antiproliferative effect on the cells as the incubation period elongated. Therefore, $0.5 \times \mathrm{IC}_{50}$, $I_{50}$ and $2 x I C_{50}$ doses of oleuropein were employed in the tests for 24,48 and $72 \mathrm{~h}$.

Table 1. Antiproliferative effects of oleuropein in MCF-7 cells

\begin{tabular}{ll}
\hline Exposure time & $\mathbf{I C}_{50}(\boldsymbol{\mu g} / \mathbf{m L}) \pm \mathbf{S D}^{*}$ \\
\hline $24 \mathrm{~h}$ & $11.02 \pm 0.52^{\mathrm{a}, \mathrm{b}}$ \\
$48 \mathrm{~h}$ & $9.43 \pm 0.41^{\mathrm{a}}$ \\
$72 \mathrm{~h}$ & $6.81 \pm 0.18^{\mathrm{b}}$ \\
\hline${ }^{*}$ significant difference between groups ${ }^{a, b} p<0.05$, \\
\multicolumn{2}{c}{ two-tailed t-test). SD: Standart Deviation }
\end{tabular}

\subsection{Impact of Oleuropein on the DNA Damage in MCF-7 Cells}

Comet assay was carried out in MCF-7 cells against oleuropein at the concentrations of $0.5 \times \mathrm{IC}_{50}, \mathrm{IC}_{50}$ and $2 \times \mathrm{IC}_{50}$ for 24,48 and $72 \mathrm{~h}$. The data are presented in Fig. 2. 


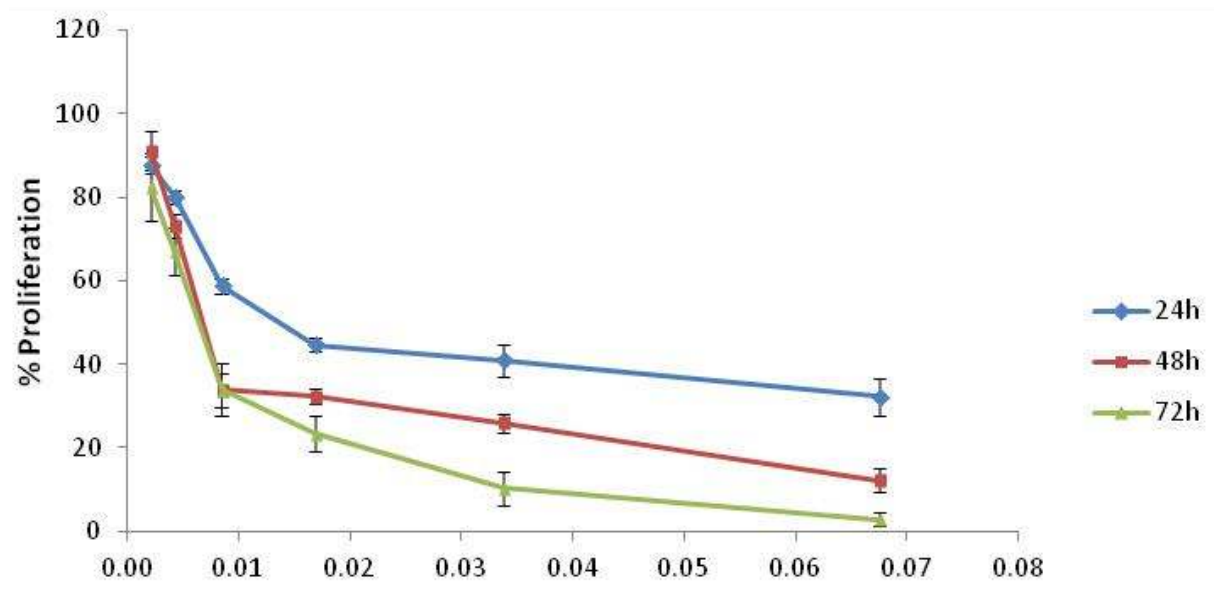

Oleuropein concentration $(\mathrm{mg} / \mathrm{mL})$

Fig. 1. Inhibition of proliferation of MCF-7 cells by oleuropein

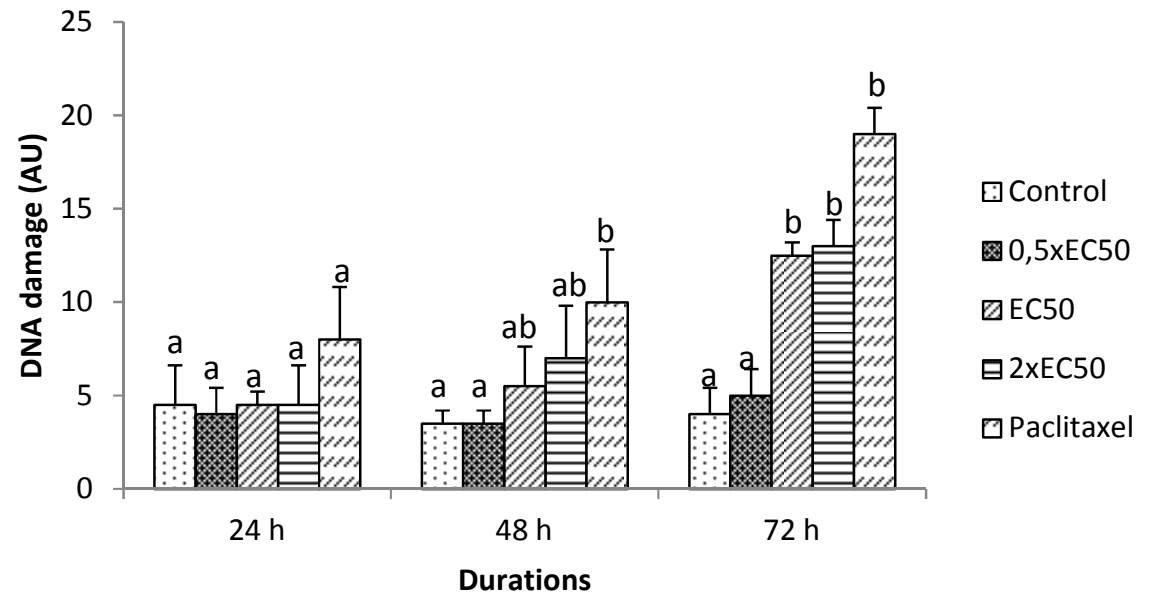

Fig. 2. Effects of oleuropein on DNA damage evaluated by the alkaline comet assay in MCF-7 cells

* Means with the same column do not differ statistically at the level of 0.05. AU: Arbitrary Unit. Data represents the mean \pm Standard deviation of three replicates

There was no statistical difference observed at $24 \mathrm{~h}$ in treated cells compared to the untreated cells. Oleuropein increased DNA damage at $\mathrm{IC}_{50}$ and $2 \times \mathrm{IC}_{50}$ for $48 \mathrm{~h}$ and at all tested concentrations for $72 \mathrm{~h}$. It was observed that there is a significant difference $(P<0.05)$ between the mean DNA damage $2 \times \mathrm{IC}_{50}$ for $48 \mathrm{~h}$, $\mathrm{IC}_{50}$ and $2 \times \mathrm{IC}_{50}$ for $72 \mathrm{~h}$ as compared to the control group. The comet assay results demonstrated that all tested concentrations of oleuropein for $72 \mathrm{~h}$ also induced damage on DNA dose dependently $(r=0.869$ $\mathrm{p}=0.005)$.

\subsection{Impact of Oleuropein on the VEGF Levels in MCF-7 Cells}

The impacts of oleuropein on the VEGF level in MCF-7 cells are shown in Fig. 3. There were dose-dependent significant decreases of VEGF $(p<0.05)$ levels in the oleuropein treatment group in comparison with the control group for the $24 \mathrm{~h}(\mathrm{r}=-0.996 \mathrm{p}=0.01), 48 \mathrm{~h}(\mathrm{r}=-$ $0.995 \mathrm{p}=0.01)$ and $72 \mathrm{~h} \quad(\mathrm{r}=-0.999$ $\mathrm{p}=0.01$ ). VEGF level of $2 \mathrm{xEC}_{50}$ was found very similar to thepositive group for the 48 and $72 \mathrm{~h}$. 


\subsection{Impact of Oleuropein on the Cleaved PARP Level in MCF-7 Cells}

Fig. 4 shows the impact of oleuropein on the cleaved PARP level in MCF-7 cells. Oleuropein significantly increased cleaved PARP level dose dependently in $24 \mathrm{~h}(\mathrm{r}=0.942 \mathrm{p}=0.01), 48 \mathrm{~h}$ $(r=0.994 \mathrm{p}=0.01)$ and $72 \mathrm{~h}(\mathrm{r}=0.993 \mathrm{p}=0.01)$. However, increased PARP levels were found to be lower when compared to the positive control group. On the other hand, cleaved PARP levels were determined to be higher in the oleuropein treatment groups when compared to the control group $(p<0.05)$.

\section{DISCUSSION}

In this study, the antitumoral activity of oleuropein on MCF-7 breast cancer was assessed by means of in vitro models. The XTT

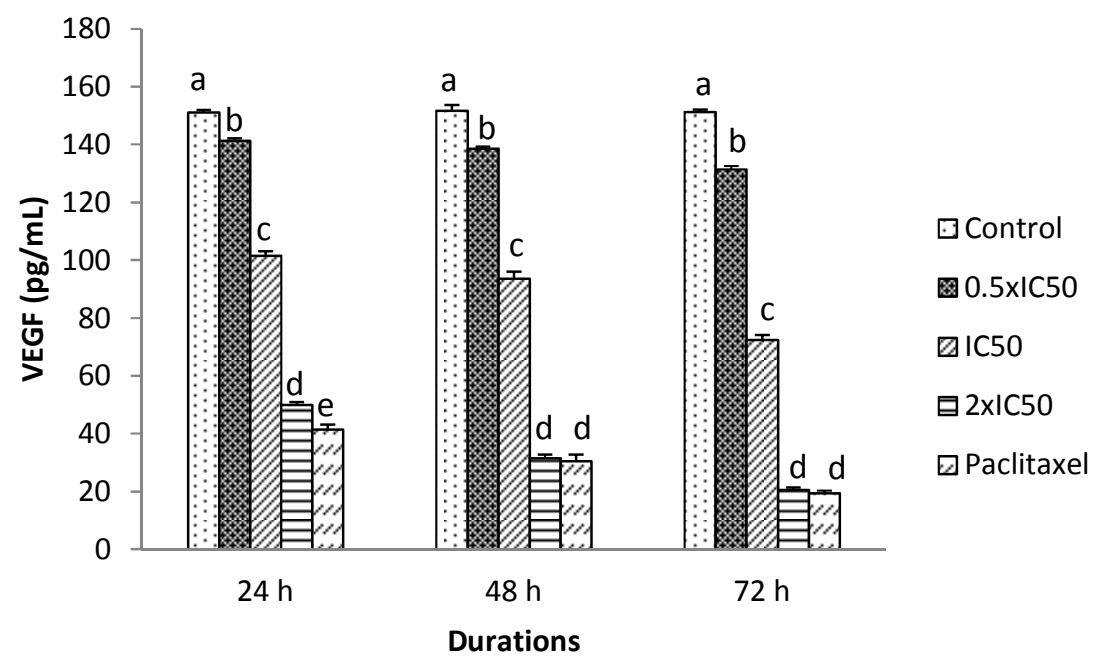

Fig. 3. Effects of oleuropein on VEGF activity in MCF-7 cells

* Means with the same column do not differ statistically at the level of 0.05. Data represents the mean \pm Standard deviation of at five replicates

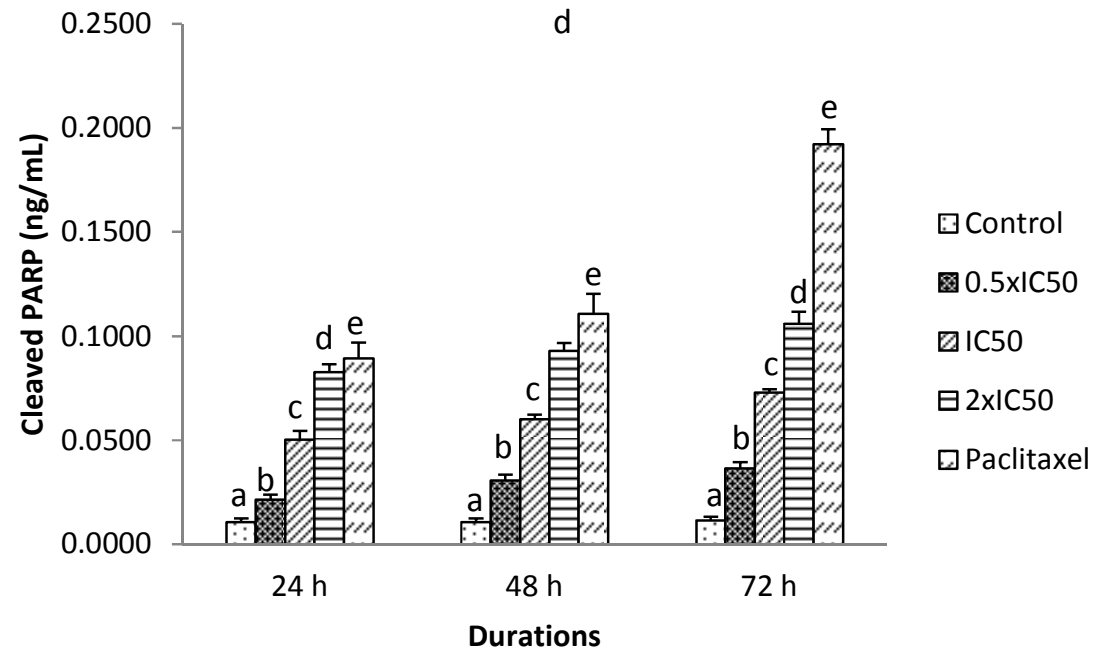

Fig. 4. Effect of oleuropein on activity cleaved PARP activity in MCF-7 cells

* Means with the same column do not differ statistically at the level of 0.05. Data represent the mean \pm Standard deviation of at five replicates 
metabolization values of MCF-7 cells decreased dose-dependently as a result of the treatment with oleuropein, which signifies an antiproliferative/proapoptotic activity. Proliferation decreased time-dependently in MCF-7 cell lines. Similarly, oleuropein inhibited cell proliferation on MCF-7 cells [11,32-36]. Oleuropein increased DNA damage at $\mathrm{IC}_{50}$ and $2 \mathrm{xIC}_{50}$ for $48 \mathrm{~h}$ and at all tested concentrations for $72 \mathrm{~h}$. A prooxidant activity is observed in oleuropein under standard culture conditions which is completely associated with the generated $\mathrm{H}_{2} \mathrm{O}_{2}$ entering cells and leading to oxidative damages because of sodium bicarbonate, being an element of most media formulation [37].

Moreover, it has alreadybeenobservedthat oleuropein treatment inhibits ultraviolet B radiation-induced skin damage [38], soft tissue sarcomas [39], and breast cancer [36]. In addition to this, the antitumor action of oleuropein can be associated with its antiangiogenic function affecting tumor cells directly. Scientists have recently concentrated their major efforts on determining and analyzing antiangiogenic compounds as therapeutics for cancer. At the moment, clinical tests examine a number of antiangiogenic agents. A large portion of these agents represent small molecule inhibitors which aim at molecular mediators of angiogenesis and growth factor receptors, for instance VEGF. Tumourigenesis in breast cancer cells is caused by the overexpression of VEGF. VEGF controls tumor advancement by means of paracrine and autocrine mechanisms. VEGF is believed to be a main proangiogenic factor for tumor endothelial cells. At the same time, it is admitted to be a survival factor for MCF-7 cells $[40,41]$. VEGF has developed as an appealing focus in the treatment strategies of antiangiogenesis $[42,43]$. In this study, oleuropein decreased higher VEGF levels. So, our findings correlate with other studies and our findings can contribute to the literature of these effects of oleuropein on MCF-7 cells [4446]. According to the findings, oleuropein is an antiangiogenic agent for MCF-7 breast cancer cells.

Oleuropein increased cleaved PARP levels. Because, PARPs can be activated in cells experiencing stress and/or DNA damage. PARP may also prompt programmed cell death via the generation of PARP. Therefore, we thought oleuropein's high doses increased DNA damage and levels of PARP by inducing cell apoptosis on MCF-7 cells. PARPs have a part in apoptosis and its cleavage inhibits the working of DNA repair enzyme. Therefore, it increases apoptosis by preventing the activation of PARP. Li et al. [47] also studied the effects of resveratrol treatment on MCF-7 cells and demonstrated PARP cleavage and significant apoptosis which signifies the role of PARP in apoptosis.

\section{CONCLUSION}

Our study refers that oleuropein possesses a potent in vivo anti-cancer activity in MCF-7 cells. For instance, due to its antioxidant property, it can protect cells from inducing genetic damage which causes oncogenesis. At the same time, the prevention of tumor progression is possible due to oleuropein's being an antiangiogenic agent. At last, tumor regression can be observed since oleuropein directly suppresses cancer cells. However, further studies are needed for anticancer effects of oleuropein for its properties.

\section{CONSENT}

It is not applicable.

\section{ETHICAL APPROVAL}

It is not applicable.

\section{ACKNOWLEDGEMENTS}

This study was supported by Usak University BAP (Project no. 2014/ÖAP001).

\section{COMPETING INTERESTS}

Authors have declared that no competing interests exist.

\section{REFERENCES}

1. Jemal A, Bray F, Center M, Ferlay J, Ward E, Forman D. Global cancerstatistics. CA Cancer J Clin. 2011;61(2):69-90.

2. Saad ED. Endpoints in advanced breast cancer: Methodological aspects \& clinical implications. Indian J Med Res. 2011; 134(4):413-418.

3. Key TJ, Schatzkin A, Willett WC, Allen NE, Spencer EA, Travis RC. Diet nutrition and the prevention of cancer. Public Health Nutr. 2004;7(1A):187-200.

4. Keys A, Aravanis C, Van B. FSP, Blackburn $\mathrm{H}$. The diet and all-causes death rate in the seven countries study. Lancet. 1981;8237:58-61. 
5. Owen RW, Mier W, Giacosa A. Hull WE, Spiegelhalder B, Bartsch $H$. Phenolic compounds and squalene in olive oils: The concentration and antioxidant potential of total phenols, simple phenols, secoiridoids, lignans and squalene. Food Chem Toxicol. 2000;38(8):647-659.

6. Owen RW, Giacosa A, Hull WE, Haubner R, Würtele G, Spiegelhalder B, Bartsch $\mathrm{H}$. Olive-oil consumption and health: The possible role of antioxidants. Lancet Oncol. 2000(b);107-112.

7. Visioli F, Galli C. Phenolics from olive oil and its waste products. Biological activities in vitro and in vivo studies. World Rev Nutr Diet. 2001;88:233-237.

8. Hassan ZK, Elamin MH, Omer SA, Daghestani $\mathrm{MH}$, Al-Olayan ES, Elobeid MA, Virk P. Oleuropein induces apoptosis via the p53 pathway in breast cancer cells. Asian Pac J. Cancer. Prev. 2014;14(11): 6739-42.

9. Fayyaz S, Aydin T, Cakir A, Gasparri ML, Panici PB, Faroogi AA. Oleuropein mediated targeting of signaling network in cancer. Curr Top Med Chem. 2016;16(22):2477-2483.

10. Giner E, Recio MC, Ríos JL, CerdáNicolás JM, Giner RM. Chemopreventive effect of oleuropein in colitis-associated colorectal cancer in c57bl/6 mice. Mol Nutr Food Res. 2016;60(2):242-55.

11. Han J, Talorete TP, Yamada P, Isoda H. Anti-proliferative and apoptotic effects of oleuropein and hydroxytyrosol on human breast cancer MCF-7 cells. Cytotechnology. 2009;59(1):45-53.

12. Carluccio MA, Siculella L, Ancora MA, Massaro M, Scoditti E, Storelli C, Visioli F, Distante A, De Caterina R. Olive oil and red wine antioxidant polyphenols inhibit endothelial activation: Antiatherogenic properties of Mediterranean diet phytochemicals. Arterioscler Thromb Vasc Biol. 2003;23(4):622-629.

13. Micol V, Caturla N, Pérez-Fons L, Más V, Pérez L, Estepa A. The olive leaf extract exhibits antiviral activity against viral haemorr hagic septicaemia rhabdo virus (VHSV). Antiviral Res. 2005;66(2-3):129136.

14. Saija A, Uccella N. Olive biophenols: Functional effects on human wellbeing. Trends Food Sci. Technol. 2000;11(910):357-363.

15. Khayyal MT, el-Ghazaly MA, Abdallah DM, Nassar NN, Okpanyi SN, Kreuter MH.
Blood pressure lowering effect of an olive leaf extract (Olea europaea) in L-NAME induced hypertension in rats. Arzneimittel Forschung. 2002;52(11):797-802.

16. Jemai H, El Feki A, Sayadi S. Antidiabetic and antioxidant effects of hydroxytyrosol and oleuropein from olive leaves in alloxan-diabetic rats. J. Agric. Food Chem. 2009;57(19):8798-8804.

17. Visioli F, Poli A, Gall C. Antioxidant and other biological activities of phenols from olives and olive oil. Med. Res. Rev. 2002;22(1):65-75.

18. Goldsmith CD, Vuong QV, Sadeqzadeh E, Stathopoulos CE, Roach PD, Scarlett CJ. Phytochemical properties and antiproliferative activity of Olea europaea L. Leaf extracts against pancreatic cancer cells. Molecules. 2015;20(7):12992-3004.

19. De Marino S, Festa C, Zollo F, Nini A, Antenucci L, Raimo G, lorizzi M. Antioxidant activity and chemical components as potential anticancer agents in the olive leaf (Olea europaea L. cv Leccino.) Decoction. Anticancer Agents Med. Chem. 2014;14(10):1376-85.

20. Peralta-Leal A, Rodríguez-Vargas JM, Aguilar-Quesada R, Rodríguez MI, Linares JL, de Almodóvar MR, Oliver FJ. PARP inhibitors: New partners in the therapy of cancer and inflammatory diseases. Free Radic Biol Med. 2009;47(1):13-26.

21. Boudreau N, Myers C. Breast cancerinduced angiogenesis: Multiple mechanisms and the role of the microenvironment. Breast Cancer Res. 2003;5:140-146.

22. Miller KD, Dul CL. Breast cancer: The role of angiogenesis and antiangiogenic therapy. Hematol Oncol Clin North Am. 2004;18:1071-1086.

23. Pepper MS. Role of matrix metalloproteinase and plasminogen activator-plasmin system in angiogenesis. Arterioscler. Thromb. Vasc. Biol. 2001;21:1104-1117.

24. Sarma $P$, Ramaiah MJ, Pal D, Bhadra U, Bhadra MP. A novel bisindole-PBD conjugate inhibits angiogenesis by regulating STAT3 and VEGF in breast cancer cells. Life Sciences. 2016;151:264276.

25. McMahon G. VEGF receptor signaling in tumour angiogenesis. Oncologist. 2000;5(Suppl. 1):3-10.

26. Chen CT, Du Y, Yamaguchi H, Hsu JM, Kuo HP, Hortobagyi GN, Hung MC. 
Targeting the IKKbeta/ mTOR/VEGF signalling pathway as a potential therapeutic strategy for obesity related breast cancer. Mol Cancer Ther. 2012;11(10):2212-2221.

27. Chekhonin VP, Shein SA, Korchagina AA, Gurina OI. VEGF in tumour progression and targeted therapy. Curr. Cancer Drug Targets. 2013;13:423-443.

28. Martin OD, Aguilar QR, O'ValleN F, Munoz GJ, Martinez RA, Garcia DMR, Almodovar $R$, Villuendas JM, Piris R, Oliver MA. Inhibition of poly(ADP-ribose) polymerase modulates tumor-related gene expression, including hypoxia-inducible factor-1 activation, during skin carcinogenesis. Cancer Res. 2006;66:5744-5756.

29. Tentori L, Lacal PM, Muzi A, Dorio AS, Leonetti C, Scarsella M, Ruffini F, Xu W, Min W, Stoppacci1aro A, Colarossi C, Wang ZQ, Zhang J, Graziani G. Poly(ADPribose) polymerase (PARP) inhibition or PARP-1 gene deletion reduces angiogenesis. Eur J Cancer. 2007;43: 2124-2133.

30. Pyriochou A, Olah G, Deitch EA, Szabo C, Papapetropoulos A. Inhibition of angiogenesis by the poly(ADP-ribose) polymerase inhibitor PJ-34. Int J Mol Med. 2008;22:113-118.

31. Çoban FK, Bulduk İ, Liman R, Ciğerci I, İnce $S$, Hazman Ö. Oleuropein alleviates malathion-induced oxidative stress and DNA damage in rats. Toxicol Environ Chem. 2016;98(1):101-108.

32. Bulotta S, Corradino R, Celano $M$, D’Agostino M, Maiuolo J, Oliverio M, Russo D. Antiproliferative and antioxidant effects on breast cancer cells of oleuropein and its semisynthetic peracetylated derivatives. Food chemistry. 2011;127(4): 1609-1614.

33. Sirianni R, Chimento A, De Luca A, Casaburi I, Rizza P, Onofrio A, lacopetta D, Puoci F, Andò S, Maggiolini M, Pezzi V. Oleuropein and hydroxytyrosol inhibit MCF-7 breast cancer cell proliferation interfering with ERK1/2 activation. Mol. Nutr. Food Res. 2010;54:833-840.

34. Elamin $\mathrm{MH}$, Daghestani $\mathrm{MH}$, Omer SA, Elobeid MA, Virk P, Al-Olayan EM, Aboussekhra A. Olive oil oleuropein has anti-breast cancer properties with higher efficiency on ER-negative cells. Food Chem Toxicol. 2013;53:310-316.

35. Chimento A, Casaburi I, Rosano C, Avena $\mathrm{P}$, De Luca A, Campana C, Sirianni R.
Oleuropein and hydroxytyrosol activate GPER/GPR30-dependent pathways leading to apoptosis of ER-negative SKBR3 breast cancer cells. MolNutr Food Res. 2014;58(3):478-489.

36. Sepporta MV, Fuccelli $R$, Rosignoli $P$, Ricci G, Servili M, Morozzi G, Fabiani R. Oleuropein inhibits tumour growth and metastases dissemination in ovariectomised nude mice with MCF-7 human breast tumour xenografts. J Funct Foods. 2014;8:269-273.

37. Odiatou EM, Skaltsounis AL, Constantinou Al. Identification of the factors responsible for the in vitro pro-oxidant and cytotoxic activities of the olive polyphenols oleuropein and hydroxytyrosol. Cancer Lett. 2013;330(1):113-121.

38. Kimura $Y$, Sumiyoshi M. Olive leaf extract and its main component oleuropein prevent chronic ultraviolet $B$ radiationinduced skin damage and carcinogenesis in hairless mice. J Nutr. 2009;139(11): 2079-2086.

39. Hamdi HK, Castellon R. Oleuropein, a non-toxic olive iridoid, is an anti-tumor agent and cytoskeleton disruptor. Biochem Biophys Res Commun. 2015;334(3):769778.

40. Pidgeon GP, Barr MP, Harmey JH, Foley DA, Bouchier-Hayes DJ. Vascular endothelial growth factor (VEGF) upregulates BCL-2 and inhibits apoptosis in human and murine mammary adenocarcinoma cells. Br. J. Cancer. 2001;85:273-278.

41. Lee TH, Seng S, Sekine M, Hinton C, Fu Y, Avraham HK. Vascular endothelial growth factor mediates intracrine survival in human breast carcinoma cells through internally expressed VEGFR1/FLT1. PLoS Med. 2007;4(6):e186.

42. Underiner TL, Ruggeri B, Gingrich DE. Development of vascular endothelial growth factor receptor (VEGFR) kinase inhibitors as anti-angiogenic agents in cancer therapy. Curr Med Chem. 2004;11:731-745.

43. Koch S, Tugues S, Li X, Gualandi L, Claesson-Welsh L. Signal transduction by vascular endothelial growth factor receptors. Biochem J. 2011;437:169183.

44. Yao J, Wu J, Yang X, Yang J, Zhang Y, Du L. Oleuropein induced apoptosis in HeLa cells via a mitochondrial apoptotic cascade associated with activation of the cJun $\mathrm{NH}$ 
2-terminal kinase. J Pharmacolog Sci. 2014;125(3):300-311.

45. Calabriso N, Massaro M, Scoditti E, D'Amore S, Gnoni A, Pellegrino M, Carluccio MA. Extra virgin olive oil rich in polyphenols modulates VEGF-induced angiogenic responses by preventing NADPH oxidase activity and expression. J Int Biochem. 2010;28:19-29.

46. Sherif IO, Nakshabandi ZM, Mohamed MA, Sarhan OM. Uroprotective effect of oleuropein in a rat model of hemorrhagic cystitis. J Int Biochem Cell Biol. 2016;74:12-17.

47. Li Y, Liu J, Liu X, Xing K, Wang Y, Li $\mathrm{F}$, Yao L. Resveratrol-induced cell inhibition of growth and apoptosis in MCF7 human breast cancer cells are associated with modulation of phosphorylated akt and caspase-9. Appl Biochem Biotechnol. 2006;135(3): 181-92.

(c) 2017 Liman et al.; This is an Open Access article distributed under the terms of the Creative Commons Attribution License (http://creativecommons.org/licenses/by/4.0), which permits unrestricted use, distribution, and reproduction in any medium, provided the original work is properly cited.

Peer-review history:

The peer review history for this paper can be accessed here: http://sciencedomain.org/review-history/18984 